\title{
Frères ennemis? Relations between Panjabi Sikhs and Muslims in the Diaspora
}

Christine Moliner

\section{(2) OpenEdition}

12 Journals

Electronic version

URL: http://journals.openedition.org/samaj/135

DOI: 10.4000/samaj.135

ISSN: $1960-6060$

Publisher

Association pour la recherche sur l'Asie du Sud (ARAS)

Electronic reference

Christine Moliner, «Frères ennemis? Relations between Panjabi Sikhs and Muslims in the Diaspora », South Asia Multidisciplinary Academic Journal [Online], 1 | 2007, Online since 14 October 2007, connection on 10 December 2020. URL : http://journals.openedition.org/samaj/135; DOI : https:// doi.org/10.4000/samaj. 135

This text was automatically generated on 10 December 2020.

\section{cc) (1) $\odot$}

This work is licensed under a Creative Commons Attribution-NonCommercial-NoDerivatives 4.0 International License. 


\title{
Frères ennemis? Relations between Panjabi Sikhs and Muslims in the Diaspora
}

\author{
Christine Moliner
}

1 In the expanding academic field of Sikh studies-in particular Sikh Diaspora studies-a topic has been under-researched: the relations between Sikhs and non Sikhs. ${ }^{1}$ The issue of the formation of a diasporic Sikh identity, as investigated in recent works, has focused on the role of political mobilisation, on the production of visual representations of the Sikhs, the process of cultural and religious transmission, the mediation of religious authorities or the internal diversity of the community along caste or sectarian lines ${ }^{2} .$. But to try to answer the seminal question of W.H. McLeod 'Who is a Sikh?' (from the title of his book, 1989), my contention is that one has also to explore Sikh constructions of alterity and representations of the other(s), as essential component of identity.

Why study Sikhs' representations of the Muslims? Following the partition of British India, the partition of the Panjab province, where they originate from, has resulted in 1947 in a huge exchange of population: Sikhs and Hindus fled to East (Indian) Panjab and Muslims to West (Pakistani) Panjab. The starting point of this study is thus to investigate if Panjabis, since they could not 'meet' (literally and metaphorically) until recently in partitioned South Asia, have managed to do so in their diasporic homes. Since I have been studying so far Sikh diasporic identity formation, I have chosen to focus only on Sikhs' representations, but this work should be completed by a reversed study of Muslims' perceptions about Sikhs. This would definitely help balance a point of view that might otherwise be considered as biased against Sikhs.

3 The conceptual framework of this study revolves around the notion of identity narratives, as defined by D.-C. Martin, particularly the role of otherness in fashioning identity. Indeed, 'identities implies the other to exist and develop; identity narrative (...) is as much a statement on the other, or the others, as a proclamation of oneself' (Martin 1995). Moreover, in this volume, Gayer reminds us that diasporic constructions of the 
other(s) are remarkable for their multiplicity and their instability. As far as diasporic Sikhs are concerned, Muslims, Hindus as well as also other ethnic minorities and the majority population, the British, are potentially all powerful figures of otherness. All instable though, as they depend on complex interactions between the global context, national (partition legacy, relations between India and Pakistan, British policy towards ethnic minorities) and even local ones (patterns of community relations differ in Southall, Birmingham or Bradford). My study of Sikh representations of the Muslims will unfold in two parts: how the Muslim has historically been constructed as a powerful symbol of otherness in Sikh identity narratives and how this has impacted on contemporary interethnic relations in the UK.

\section{Figure of the Other in Sikh historic and religious corpus}

Sikh religious corpus offers an apt starting point to understand how the Muslim has been historically constructed as the Other in Sikh imaginary. Indeed, Sikh religious and historical texts are replete with references to Muslims, Mughals and Afghans but these references convey heterogeneous, equivocal, sometimes contradictory representations, in any case far more complex than implied by later interpretations. Two opposite themes run across this literature: one that insists on the fraternity (bhaichara) between Sikhs and Muslims, the other highlighting a supposed hereditary antagonism between them.

\section{Bhaichara paradigm}

5 As shown in H. McLeod's authoritative translation and study of Sikh textual sources (1984), there are no representations of the Muslim (or the Hindu) as the Other in Sikh major scriptures, such as the Adi Granth or the Dasam Granth. And this very absence upholds McLeod's contention about there being no fixed religious boundaries in early Sikhism.

6 The references to Hindus and Muslims convey one message: that of the unity of mankind under one God. But this fundamental truth is concealed by meaningless doctrines and rituals, which artificially divide mankind. One of the most forceful expressions of this irenic belief is to be found in a famous passage of the Dasam Granth:

Some are called Hindus, others are Muslims, members of sects such as Shia or Sunni.

Let it be known that mankind is one, that all men belong to a single humanity.

So too with God, whom Hindu and Muslim distinguish with differing names.

Let none be misled, for God is but one; he who denies this is duped and deluded.

There is no difference between a temple and a mosque, nor between the prayers of a Hindu or a Muslim.

Though differences seem to mark and distinguish, all men in reality are the same. Gods and demons, celestial beings, men called Muslims and others called Hindussuch differences are trivial, inconsequential, the outward results of locality and dress.

Allah is the same as the God of the Hindus, Puran and Qur'an are one and the same... (Dasam Granth, Akal Ustat, in McLeod's translation 1987: 57).

7 When Guru Nanak criticises conventional religions, he is targeting the two symbols of religious orthodoxy of his time, the pandit and the maulvi. ${ }^{3}$ This condemnation of 
orthodoxy, of a ritualistic and outward observance of religion, is typical of the Sant tradition from which early Sikhism has emerged in the $15^{\text {th }}$ century. Besides this critique of external devotion, the motive of 'Baba Nanak the Unifier' comes out strongly in the Janam-Sakhi literature (hagiographies of Guru Nanak). He is repeatedly represented as a conciliator between Hindus and Muslims, from his birth-solemnised by local Muslims and Hindus-to his death-when his corpse is claimed by both communities, the former asking to bury him, the latter to cremate him. Always accompanied by his two disciples, Bala the Hindu and Mardana the Muslim, Guru Nanak as described in the Janam-Sakhi tradition is mixing symbols, customs and even garments belonging to the two religious affiliations.

This irenic representation of Guru Nanak has gained momentum in the course of Sikh history and is today appropriated by those advocating for tolerance and better understanding between Sikhs and Muslims. This interpretation is developed by Yoginder Sikand, in particular in his text 'Re-imagining Sikh-Muslim relations in the light of the life of Baba Nanak' or his interview of Makhdoom Syed Chan Pir Qadri on Sikh-Muslim relations, where the Pir emphasizes the close spiritual relationship between some Sikh Gurus and the Sufis (the Pir himself is custodian of the dargah of the famous Qadiri Sufi Mian Mir from Lahore who laid the foundation stone of the Harmandir Sahib at the request of the fifth Sikh Guru).

\section{The antagonist paradigm}

9 All these religious and historical elements attesting a non-conflictual co-existence and shared religious practices between Muslims and Sikhs have been completely marginalised from the $18^{\text {th }}$ century onwards, in the process of Sikh identity formation that entailed the construction of rigid boundaries between Sikhs, Muslims and Hindus and in particular the elaboration of Sikh representations of the 'Musulman' as the dangerous other.

These representations are grounded in a specific corpus, both liturgical and historical: the Rahitnamas ('Books of code'), the Gurbilas ('Glory of the Guru') and the martyrologies of the late $19^{\text {th }}$-early $20^{\text {th }}$ century socio-religious reform movement called the Singh Sabha ('Society of the Lions'). In this type of literature, the creation of the Khalsa ${ }^{5}$ in 1699 appears as the rupture point in the history of the Panth. One should here distinguish between the historical event itself and the ways it has later been interpreted: the later only will be of interest for our purpose. Sikh traditional historiography, a product of the Singh Sabha reform movement, sees the creation of the Khalsa order as a response by the $10^{\text {th }}$ Guru to Mughal oppression. According to tradition, Guru Gobind Singh wanted to transform his peaceful disciples into valiant soldiers able to overthrow Mughal power, to transform sheep into lions (Singh). This spectacular transformation was to be achieved through a distinctive initiation ceremony (khande di pahul), to impart them with a martial spirit, a sense of sacrifice for the sake of righteousness and through a rigorous code of conduct (Khalsa Rahit) to fashion a separate and visible identity, and to make it impossible for Singhs to conceal themselves in the face of the oppressor.

The Rahitnamas, those manuals recording the Rahit, prescribe ritual practices and social obligations, some of which are illustrative of a growing sense of the Muslim as the other. The Chaupa Singh Rahit Nama, studied and translated by McLeod (1987), illustrates explicitly this anti-muslim theme grounded in the $18^{\text {th }}$ century tense context, through the following list of prohibitions: 
Never associate with a Muslim nor trust his word.

Never drink water from a Muslim's hands, never eat his food,

And never sleep in his company.

Do not be influenced by anything which a Muslim may say,

Never touch a Muslim woman.

Never eat meat from animals killed according to Muslim rites (...)

Hence the Rahit Maryada (the modern form of the Rahit) strictly prohibits for amritdhari Sikhs (lit. those who took the baptismal nectar called amrit, during the initiation ceremony) four kurahit (lit. 'bad rules of behaviour'): cutting one's hair, eating halal meat, having extra marital sexual intercourse, smoking tobacco. While at least two of those practices (halal meat and tobacco) are clearly associated with Muslims, in the case of the third kurahit, it is more covert. If we are to follow McLeod's analysis, this kurahit is the contemporary rendition of an older one, prohibiting intercourse with Muslim women.

The Gurbilas and the Singh Sabha martyrologies also bear the imprint of the confrontation with the Mughals and contributed greatly to the conflictual narrative that permeates, even till today, Sikh collective imaginary, whereas the bhaichara one has remained at the periphery.

This rhetoric of confrontation is articulated around what Veena Das calls the 'HinduSikh-Muslim triad' (Das 1992), where the Sikh plays the martyr, the Muslim the oppressor and the Hindu a more ambiguous role, either victim or traitor, at best an unreliable ally of the Sikh against the Muslim. The martyrdom of the ninth Guru, Tegh Bahadur, exemplifies these complex relations.

Before that, the death of the fifth Guru in 1606 under the orders of Emperor Jahangir dramatically initiated a new phase in Sikh history, marked by the hostility of Mughal administration and the ensuing shift of the Sikhs from a quietist community to a martial one. Thirty years later the conflict had become even more acute between the Sikhs and the Mughal Emperor Aurangzeb, who figures prominently in Sikh demonology, depicted as a tyrant, a fanatical Muslim willing to convert to Islam the whole of India. Kashmiri Brahmins, threatened of forced conversion by Aurangzeb, appealed to Guru Teg Bahadur for help. The Guru's challenge to Aurangzeb, 'If you manage to convert me, then all nonMuslims will also embrace Islam', lead to his decapitation in November 1675 in Delhi.

Let's examine the multiple interpretations of this critical event in Sikh history. According to traditional Sikh historiography, the conflict was a religious one, opposing a fanatical Muslim tyrant and the Sikh Guru, ready to sacrifice his life for the sake of religious freedom, in that particular instance of a community other than his own. This last point is important in Sikhs perception of themselves as defenders of the weak and the oppressed. Muslims have a completely different reading of the period: the conflict between Aurangzeb and the Guru was politically motivated, as the Sikhs were posing a threat to Mughal power. The Arya Samaj and Hindu nationalists propose yet another interpretation: the Guru died to protect his own dharma, and that interpretation underscores their reinterpretation of Sikhism as the sword arm of Hinduism against a common enemy, the Muslim.

The polysemic aspect of the event should not distract us however from the fact that only the first interpretation is regarded as the accurate one among Sikhs. Sikh traditional understanding of this event is archetypal of the triad mentioned above, Aurangzeb as the oppressor, the Kashmiri Brahmins as the victims (but also as the taunts, in some accounts) and the Guru as the martyr. At the centre stands the martyrdom of Guru Tegh 
Bahadur. Here we touch upon the pre-eminent role of the martyr in Sikh history, what Lou Fenech calls the rhetoric of martyrdom (2003) that is central to our analysis of Sikhs' portrayal of their collective self and of the Muslim Other. I will develop this point below when talking about the Singh Sabha.

The Gurbilas epitomize this anti-Islamic theme (Fenech 2003: 123-9). They are $18^{\text {th }}$ century hagiographical accounts of the sixth and tenth Sikh Gurus, highlighting their military skills and courage, the martial ethos they wanted to impart on the Sikhs-an approach to the lives of the Gurus very different from the Janam Sakhi literature mentioned above. As we can expect, the Muslim figures prominently, in this literature, as the persecutor: to praise the heroism and self-sacrifice of the Sikhs, one needs a villain as cruel and fiendish as possible. Without a tormentor, there is no martyr: the fiercer the persecutions, the bigger the heroism of the martyr. In a teleological perspective, we can even consider the Muslim as God's instrument to reveal to the Sikhs their collective destiny-Raj Karega Khalsa, 'the Khalsa shall rule'. Therefore, in Sikh historiography, the $18^{\text {th }}$ century is a period of great hardship, of persecutions ( the two great holocausts ) in the hands of a cruel enemy, but a golden age too, foretelling triumph and glory for the Panth, ${ }^{6}$ symbolised by Ranjit Singh's entry into Lahore in 1799.

If we turn now to Singh Sabha literature and its representations of the Muslim, we can at first agree with Fenech's statement that 'the anti-Muslim bias characteristic of the $18^{\text {th }}$ century Sikh literature was not as pronounced in the literature of the $19^{\text {th }}$ century' (Fenech 2003: 10). Indeed some of the crudest components of the anti-Islam theme as present in the Rahitnamas and the Gurbilas have been expurgated by the Singh Sabha reformists. Hence, the Singh Sabha recasting of the Rahit, that was to ultimately lead to the promulgation of the current Rahit Maryada in 1950, illustrates this euphemisation trend. The Rahit Maryada is purged from any overtly anti-Muslim elements, such as the prohibitions quoted above from the Chaupa Singh Rahit Nama (see for instance the prohibition of sexual intercourse with a Muslim woman rephrased as 'cohabiting with a person other than one's spouse', SGPC 1997: chapter 13).

How can we explain this shift in Sikh discourse? Fenech refers to Sikh dominance of the Panjab under Ranjit Singh and his displacement of Mughal rule as a possible explanation, $\mathrm{H}$. McLeod to the influence of colonial understanding of communal relations, deligitimizing open expressions of enmity (Fenech 2003, McLeod 1999). But most crucially, the project of the Singh Sabha to redefine Sikh identity created a new figure of Otherness, the Hindu. The Tat Khalsa, the Singh Sabha radical wing that ultimately gained prominence, wanted to demonstrate that the Sikhs are a separate community, distinct from both Hindus and Muslims. Sikhs' distinctiveness from Muslims didn't need much elaboration then, as the Muslim has routinely embodied the Other since the $18^{\text {th }}$ century.

The Singh Sabha primary concern was thus to demonstrate that Sikhs were not Hindus, as illustrated in a famous pamphlet published in the late $19^{\text {th }}$ century, Ham Hindu Nahin ('We are not Hindus'). As we can infer from its title, it was first written in Hindi $^{7}$ and addressed as much to Hindus as to Sikhs and since then it has become a classic proclamation of Sikh identity as reinterpreted by the Singh Sabha of which Bhai Kahn Singh, its author, was an eminent protagonist. It was released in a context of strong antagonism between the Tat Khalsa and the Arya Samaj whom the former identified as the new enemy of the Panth. Indeed, Sikhs resented very much the derogatory statements on the Sikh Gurus made by Swami Dayananda, the leader of the Samaj, and more generally opposed the Samaj's 
contention that Sikhism is merely the militant branch of Hinduism (Jones 1973). This antagonism was made all the more acute by the conversion issue. Christian mass conversions, mostly of low castes and untouchables, led Hindu, Sikh and Muslim reform movements into an aggressive and competitive proselytism, of which Panjab became the privileged ground from the 1880s. It is noteworthy that the first Singh Sabha was set up in Amritsar, in reaction to the conversion of Sikh students to Christianity in 1873.

It is also in the Panjab that the Arya Samaj developed its own ritual of conversion, shuddhi , initially used to readmit Hindus who had converted to Islam or Christianity but then extended to purify Hindu and Sikh untouchables (Jones 1976). Besides the Arya Samaj and the Church, the Ahmeddyia were also prominent in these conversion activities, targeting specifically Sikhs. But Arya activism was increasingly perceived by Sikh reformists as the greatest of all threats, all the more that this perception found an echo in colonial ideology. For instance, a recurring theme of British orientalism, that of Sikhism in danger of re-absorption into Hinduism, was re-appropriated by the Tat Khalsa and fed their antagonism with the Arya Samaj. According to a famous phrase by Macauliffe:

Hinduism (...) is like the boa constrictor of the Indian forests. When a petty enemy appears to worry it, it winds round its opponent, crushes it in its folds and finally causes it to disappear (...) in this way it is disposing of the reformed and once hopeful religion of Baba Nanak (...) [that is] making a vigorous struggle for life, but its ultimate destruction is inevitable without State support (Macauliffe 1909).

Sikhs hold the weakest position in the triad, since their quest for recognition of the Panth as the third Qaum was opposed not only by both Muslims and more strenuously so Hindus, but also within their own ranks. At par with the Arya Samaj, the Tat Khalsa targeted another enemy, all the more dangerous that it was an insider: the Sikhs' 'ignorance' about their true identity, misconstructed as part of Hinduism by Tat Khalsa opponents, the Sanatan (traditional) Sikhs, prominent in the Amritsar Singh Sabha and very active in the Arya Samaj. Within a complex social fabric characterised, in $19^{\text {th }}$ century Panjab, by the plurality, the flexibility and the interpenetration of communal identities, the Singh Sabha reformers undertook to draw clear-cut boundaries between Sikhs and other Panjabis, and to impose these boundaries on Sikhs and non-Sikhs alike. I shall come now to the Singh Sabha usage of martyrdom, alluded to above, in establishing the limits of this separate identity, as superbly analysed by Fenech (2003). This rhetoric of martyrdom, to use his phrase, appears quite relevant to our present study as it entails a specific construction of the Self as victim and of the Others as inimical figures.

What is the correlation between martyrdom and collective identity? Fenech demonstrates how 'martyrdom also deals with identity, and dramatically so (...) In his horrific death, the Sikh martyr was made to resolutely proclaim the separate identity of the Sikh Panth' (Fenech 2003: 19). To the point that 'Sikh community comes together symbolically in the martyr and is substantiated and made public through martyrdom' (Fenech 2003: 22). To understand this correlation, we have to come back to the heroic period of the Panth, the $18^{\text {th }}$ century, as it is perceived by Sikhs since the Singh Sabha period. Let's not forget that according to Sikh tradition the Khalsa was created to resist Mughal attempt to annihilate the Panth, it is therefore in a situation of conflict with the Muslims that this major identity shift occurred. Sikhs were persecuted, so the tradition goes, by a tyrannical enemy and resisted till death to uphold their faith. As the Arabic term shahid (widely used by Sikhs since the $19^{\text {th }}$ century to refer to their martyrs) implies, they were witnesses to truth through the sacrifice of their life. It is particularly in defence of the visible symbols of the faith-especially kesh, the hair and the turban-that they were martyred. Their 
sacrifice became, in the hands of the Singh Sabha, a powerful tool firstly to promote Khalsa identity and deligitimize non-Khalsa ones, and secondly to proclaim the separate identity of the Sikhs. Their martyrdom rhetoric therefore consolidated both inner boundaries (between Khalsa and non-Khalsa) and outer ones (between Sikhs and nonSikhs).

Interesting is also the reinterpretation of the past implied here. This is not specific to the Singh Sabha, as their Muslim and Hindu counterparts have engaged in the same task. I have already mentioned how some key events have given way to very different, often contradictory, communal interpretations (see for instance the martyrdom of Guru Tegh Bahadur or the reign of Ranjit Singh, hailed by the Sikhs, dreaded by the Muslims). I wish now to underscore firstly how the Singh Sabha has fashioned Sikh history as the history of martyrdom and secondly how it has established continuity, contemporaneity between selected past events and the present. ${ }^{8}$ And this primacy of martyrdom and the continuity between past and present are bearing, still today, a strong imprint on Sikh collective imaginary.

Sikh historiography indeed lies on a systematic forgetting of not-so-heroic incidents, and a contrario, on a selection of events which portray the Panth in the best possible light. Hence, Persian sources referring to Sikhs' conversion to Islam are conveniently ignored, so too the infighting or the looting characteristic of the misl (warrior bands), in the second half of the $18^{\text {th }}$ century (Fenech 2003:100). Likewise Sikh participation in the communal riots of the 1920s and 1940s and in the carnage of the partition is not acknowledged. As stated by Veena Das (1992), all acts of violence are constructed as the violence of martyrdom, any evil acts being projected on the Other (Hindu or Muslim).

As for our second point, the contemporaneity between the past (a reconstructed one) and the present, a correlation is consistently drawn between struggles, threats and enemies of the past and those of the present. It is true at the turn of the $20^{\text {th }}$ century, when the Arya Samaj first and later, during the Gurdwara Reform Movement in the 1920s, the Mahants (Hindu custodians of the Gurdwaras) are equated with the dreaded Afghans and Mughals of the $18^{\text {th }}$ century. It is also true in the 1980 s, during the confrontation of Sikh neofundamentalists with the central Indian State, perceived as a dominating and aggressive Hindu entity, a confrontation projected as the continuation of a long series of struggles to preserve Sikh identity.

The Sikh-Hindu-Muslim triad is therefore constantly renegotiated and submitted to an evolving political context. Hence, the Singh Sabha concern to demonstrate that Sikhs are not Hindus tended to euphemize the anti-Muslim theme and to identify the Hindu as the new enemy. Likewise, Veena Das shows how Muslim/Sikh antagonism has been neutralised in contemporary Sikh militant discourse.

But it is my contention that Sikh/Muslim antinomy remains constitutive of Sikh collective imaginary and surfaces therefore very easily. Hence, after a relatively peaceful communal climate following the imposition of the Pax Britannica in Panjab in the second half of the $19^{\text {th }}$ century, the first half of the twentieth was a contrario characterised by an increasingly tense and conflictual context, marked out by the issue of a separate electorate granted to Muslims in 1909, by the heightened competition between communities for a larger share of political representation and power, and by the launching of the Pakistan movement by the Muslim League in the early 1940s. The resulting communal riots of the 1920s and 1940s followed a well known pattern, with Sikhs and Hindus allied against Muslims. 
29 I would like to illustrate this point with two events, of very unequal historical importance: the execution of Lachman Singh in 1909 and, in the few months preceding partition, Sikhs' reactions (particularly those of the Akalis) to the Pakistan demand. Fenech opens his analysis of the Singh Sabha rhetorical use of martyrdom with the story of Lachman Singh, hanged in June 1909 for the murder of three Muslims, who had converted to Islam a Hindu lambadar (village chief) (Fenech 2003: 178-89). This seemingly anecdotic event is in fact highly revealing. Let's notice first that it occurred in the wake of the Morley-Minto reforms, granting, as mentioned above, separate electorate for Muslims, but not for Sikhs, despite their repeating demands. Secondly, the issue of conversion appears as central in Lachman Singh's act. As discussed above, it raised, among community leaders, fear of numerical and therefore political decline and increased communal competition and conflicts. And in the case of Sikhs, one cannot fail to draw a parallel with the spectre of persecutions and forced conversions to Islam of the $18^{\text {th }}$ century. Remarkably, Lachman Singh story follows the same pattern of the martyrvictim-oppressor triangular relationship that I have already mentioned. Indeed, if we are to follow Fenech's interpretation, Lachman Singh, who considered himself and was regarded by his contemporaries as a shahid, was most probably influenced by Sikh martyrologies describing Sikh suffering under Mughal tyranny and depicting the Khalsa as the protector of the Hindus.

The second example I wish to dwell on brings us some 35 years ahead, during the few months preceding the partition of India. A period of great instability and uncertainty for the Sikhs, who greatly objected to the creation of Pakistan then to the idea of partition, and supported various counter-schemes such as Azad Panjab, Sikhistan or Khalistan, opposed by both the Congress and the League. ${ }^{9}$ When it became clear that Pakistan would finally be conceded by the British, but the shape and substance of it remained very vague, the Akalis raised with an increasing vigour the spectre of a Muslim Raj, imposed on the Sikh minority. In a famous episode, their leader, Master Tara Singh, came out of the Panjab Assembly on 4th March 1947 shouting 'Pakistan murdabad, Sat Sri Akal' (death onto Pakistan, followed by the Sikh greeting) and delivering an incensed speech: 'O, Hindus and Sikhs! Your trials await you. Be ready for self-destruction like the Japs and the Nazis (...). We crushed Mughlistan and we shall trample Pakistan (...)'(Talbot \& Singh 1999: 142). Similar speeches were delivered by leaders of the three communities, equally busy in preparing for civil war. The carefully nurtured memory of past conflicts played a major part in the outburst of violence surrounding partition-and this is especially true of Muslim-Sikh antagonism.

31 Among its most gruesome episodes figures the story of Thoa Khalsa, ${ }^{10}$ a West Panjabi village where 90 Sikh women committed mass suicide not to fall in the hands of thousands of armed Muslims surrounding them. In the accounts of survivors and in the various contemporary accounts, the women are depicted as shahid, faithful to 'Sikh tradition of courage and self-sacrifice', hailed as 'daughters of Guru Arjan', equated with $18^{\text {th }}$ century martyrs, ready to give their life to safeguard their honour, and by extension that of their community (Butalia 1998, Pandey 2001).

In each community, the collective memory of such events has been kept alive, based on the projection of all evil acts on the other side, and sanctified by the nationalist narrative of the two newly created states. This partition of memory was all the easier in the case of Panjab that partition of the territory led to an entire exchange of population, to the extent that there are no Hindus and Sikhs left in West Panjab and hardly any Muslims in 
East Panjab (except for the former principality of Malherkotla and Qadian).$^{11}$ Therefore, it is only abroad that Sikh, Hindu and Muslim Panjabis have had until recently the opportunity to meet. But did they really meet in the diaspora? Here is the question I wish now to address.

\section{Reinvention of the two paradigms in a diasporic context}

33 I wish here to study how these representations of the Muslim 'Other', oscillating between bhaichara and hereditary antagonism (the latter paradigm overpowering Sikh collective imaginary), are transposed in a diasporic context; how they influence inter-ethnic relations, without entirely fashioning them, how in particular they interact with the specific socio-political context of the host society.

\section{The British context}

Let's first consider the ideological and political context of post-war Britain in relation to the mass-migration of its former colonial subjects. Sociologists have established a linkage between colonial representations and policy vis a vis the various communities the British ruled-in particular their role in fostering sharply defined communal identities-and British policy towards immigrants in post-colonial Britain. This policy, as it culminated in the 1980s, deals with communities, not individuals as in France, defined primarily, in the case of South Asians, in terms of religious affiliation. It has more specifically institutionalized and legitimized the most conservative or orthodox definitions of these identities. This has had several consequences: South Asian community leaders are primarily religious leaders (specially so in the case of Sikhs and Muslims); religious-based organisations have received the greatest share of public support and funding, they have been more successful at mobilising immigrants than pan-Asian or pan-Indian ones and they do so on religious issues (the turban of the Sikhs, the provision of halal meat in school for Muslim children...). In short, communities are encouraged to stress their cultural specificities, while competing for public resources and recognition, and in this process minority identities tend to be reified and institutionalised.

In this competition, British Sikhs took the lead in the late 1950s. Their mobilisation for the right to wear the turban (as a bus driver, then on a motorcycle or in school) culminated in a House of Lords ruling of 1982, granting them the status of an ethnic group. This specific recognition allowed them to benefit from the legislation against discrimination (paradoxically defined on ethnic or racial grounds, not religious one) that has been so far denied to Muslims.

Emulating the Sikhs, British Muslims have from the early 1990s been prominent in this 'race' to specific provisions so much so that other communities, specially after 11 September 2001, sense that Muslims are been 'pampered' by British authorities (despite abundant evidence of discrimination against them). British multicultural policy, although officially striving for the opposite, has resulted in stiff competition between communities, defined internally as homogenous and externally by rigid boundaries. 


\section{Muslim/Sikh antagonism reinterpreted in Britain}

36 I wish firstly to allude to the methodological aspects of this question: how does one investigate about constructions of otherness? I have encountered in my interviews the same 'censure on declared or open enmity' (Baumann 1997: 22) with other communities as noted by other observers (see Baumann 1997, Gayer in this volume). So much so that I quickly decided to avoid direct questioning on the issue of relations with the Muslims. But it popped in by the backdoor, so to say, and in that respect, the most interesting information was definitely drawn from participant observation and informal interviews. Community literature published by various British Sikh organisations and gurdwaras has also been a valuable source.

37 I have identified three recurring themes in my interviews and in community literature: the issue of proselytism, the status of women, and the prohibition of sexual relations across communal boundaries. The first one, particularly prominent among Sikh students, revolves around the proselytism of Muslim fellow students on campuses. Christian proselytism is also resented, and Sikhs perceive themselves as easy prey to the allegedly aggressive conversion activities of those two groups. The issue of conversion, discussed above in the colonial context, is crucial in perceptions of the Self and the Other(s). Sikhs impute proselytism to Christians and Muslims and despite the thousands of Western converts (the Gore Sikhs) claim that Sikhism is a non-proselytising religion. This results in a sense of threat, a perceived weakness vis a vis aggressive and numerically dominant Others.

The ensuing tensions to 'protect' one's faith are interpreted as re-enactment of past conflicts- those of the $18^{\text {th }}$ century adding to those of the twentieth like layers of antagonism. More specifically, the issue of forced conversions to Islam either under the Mughals or during partition still weighs on Sikh collective representations of the Muslims -hence I was told several times that 'if it hadn't been for the Sikh Gurus, the whole of India would be Muslim now'. Notably, in the diaspora, conflicting memories are not imported as such but reinvented, and in this case, reinforced by the West own perceptions and fears about radical Islam- hence the influence of such external events as the Iranian revolution, the Rushdie affair, the Islamic scarf issue, the $11^{\text {th }}$ September or the $7^{\text {th }}$ July bombing on inter-community relations in Western host countries.

Two pamphlets illustrate vividly my point: A Challenge to Sikhism by G.S. Sidhu, published in 1999 for the tricentennary celebrations of the Khalsa and Sikh Religion and Islam, A Comparative Study, by the same author with Gurmukh Singh as co-author, published in 2001. Both these works belong to the expanding genre of educational and religious Sikh literature written for the second and third generations of pardesi (Sikhs settled abroad). In this case written and published in the UK, the two pamphlets strive to alert 'young educated Sikhs' to the 'ill-intentioned attempts to misrepresent Sikh ideology and (...) history', to teach them how 'these overt and covert attacks on Sikhism (...) can be repulsed' (Introduction to A Challenge to Sikhism). Where do these attacks originate from? 'Extracts from Muslim publications in the last part of this book show the one-sided nature of these attacks of a highly inflammatory nature' (Idem), whereas the foreword to the second booklet points at the 'systematic misrepresentation of both Sikhism, and importantly, the high ideals of Islam, by some zealous Muslims, particularly in schools and university campuses'. At the core of these distortions lies the figure of Guru Nanak, 
whose 'indisputable position as a socio-religious revolutionary' (Introduction to Challenge) and founder of a world religion is constantly denied by some Muslims quarters. So at stake is the demonstration of the true nature of Sikhism as a separate religion.

The arguments are not new-these works and the genre as the whole owe much to Singh Sabha rhetoric-and they draw on earlier controversies. But interestingly, they are also the product of international migration, of the encounter of Sikhs and Muslims in the West and are fashioned by British multicultural context, more specifically by the well established practice of interfaith dialogue, in which Sikhs (mainly through the Sikh Missionary Society, based in Southall) have been quite active. The foreword to Sikh Religion and Islam highlights the importance of interfaith dialogue in such a pluralist society as contemporary Britain, and its difficulties too, as 'some religions, notably, Christianity and Islam, have missionary zeal'. As a compilation of the correspondence exchanged over several months between the author, a member of the Sikh Missionary Society, and a Panjabi Muslim he had sympathised with at inter-faith meetings in the South of England, A Challenge to Sikhism appears as a failed attempt at interfaith dialogue. Letters from the Muslim correspondent to G.S. Sidhu are indeed very offending, his repeated attempts to prove the superiority of Islam over Sikhism understandably upset the author, and fall rather short of a true spirit of dialogue. G.S. Sidhu's stand appears as an interesting mixture of traditional Sikh scholarship (in the line of the Singh Sabha) with a genuine attempt at dialogue and the usual representations of the Muslim as the dangerous Other, framed in a diasporic context.

The second topic I have come across relates to the comparative status of women in Sikhism and Islam. Sikhs endo-definitions being antonymous with their perceptions of the Muslims, Sikhism is defined as an egalitarian religion, encouraging the participation of women in the religious and social domains, banning discrimination against women, discouraging the practice of purdah. Their understanding of the status of women in Islam revolves around a cluster of practices seen as emblematic: polygamy, veiling of women, divorce by triple talaq, two women being equal to one man as witness. A brochure edited by the Sikh Woman's Awareness Network Islam and Sikhism: a Comparative View on Women (published by the Akaal Purkh KI Fauj UK, in 1998) develops in a moderate form this theme, under the following headings: salvation; education; hereditary rights; gender equality; importance of woman's view; opportunity to pray; restrictions on clothes; menstruation; marriage. The text deals with this topic exclusively through lengthy quotations from the Quran and the Guru Granth Sahib. This purely textual and normative approach allows for a maximum of differentiation between the two religious traditions. It also conveniently leaves aside the question of actual religious and social practices, shared by Sikhs and Muslims, and in fact by all Panjabis.

Thirdly, the issue of exogamous relationships is potentially the most conflictual one. It evinces in both communities a complex array of collective emotions, fantasies and representations, fed by traumatic past events and reconfigured in Britain. Endogamous marriage remains the norm among South Asians in Britain, and exogamy difficult to accept, particularly by the girl's family and community. In South Asia, women are the repository of the community's izzat (honour), hence potentially the instrument of its defilement. Their male relatives have therefore the responsibility to enforce community norms, and impose 'appropriate' behaviour. This patriarchal control of women, of their body and their sexuality, usually understood with reference to 'traditional values', is in fact a by-product of transnational migration and fits in a complex set of relations 
between ethnicity, gender and class and in particular relates to social constructs of masculinities of marginalised groups. ${ }^{12}$

The prohibition of relationships outside one's community is therefore not specific to Sikhs, but it takes on a specific shape when involving Muslims. The issue of 'our girls' being taken away by Muslims', a regular feature in my informal interviews and in various forums and chats on the net, is sensitive and potentially conflictual because of its close relation to the first point of my argument, the fear of (forced) conversion, and indirectly to the second, the status of women. In this kind of narratives, Sikh girls are considered as easy prey for Muslim boys: because of the equal status granted to them by Sikhism, they are allowed to mix much more freely with men; some Muslim men, finding it too difficult and dangerous to engage in a relation with a girl from their own community, will therefore 'target' Sikh girls, who incidentally happen to be particularly beautiful (so the contention goes...). These boys are supposedly motivated by religious extremism and their will to convert the Sikhs to Islam. In South Asia, conversion of a woman, following her marriage, leads to that of her children, who then belong to the father's family and community. As in the case of exogamous relationships, the community of the girl feels its integrity, its izzat threatened.

These social constructs conjure up the spectre of partition, of the mass-rapes, abductions and forced conversions of women, perceived as a national shame (on the South Asian notion of sharam, see S. Rushdie's Shame). To illustrate my point, I shall refer to the protest that met the proposed release of a Pakistani film in the UK in November 2003. Larki Panjaaban (a Panjabi girl) tells the story of a Sikh girl from India who while in Pakistan with her family to visit Sikh shrines falls in love with a Pakistani boy. Her family when discovering this relationship sends her to Malaysia, where her Pakistani lover manages to meet her and finally marry her. In the original script, she converts to Islam, and soon after it is found that after all she was originally a Muslim who had been brought up by Sikhs. The film was widely publicized as the first Lollywood (from the Lahore-based film industry) 'cross-border love story' and symbolically was due to be released at the same time in India, Pakistan and England. Interestingly, some British Sikhs (mostly from the Muslim-Sikh Federation) greatly objected to the conversion bit of the story and successfully put pressure on the film director, based in Bradford, to alter the script so that the girl remained Sikh.

\section{Commonalities and transcending of religious and national cleavages: between South Asian identity and Panjabyat}

However, British Sikhs and Muslims share a common migration experience. They migrated predominantly from rural areas to post-industrial Britain as a replacement workforce, much needed in a post-war reconstruction economy. They belong to dominant rural castes (the Jats), and originate from delimited areas, mainly from the Doaba (the central districts of East Panjab) in the case of Sikhs, from Mirpur (in Azad Kashmir), Faisalabad and Jhelum districts (in West Panjab) in that of Muslims.

Their migration history and patterns of settlement are also quite similar. Involved in a process of chain migration, the pioneers relied on the biradari (clan) to settle down. Concentrated in the same regions, mostly Greater London and the Midlands, in the same inner cities areas, they were at first engaged in the same occupations. But after the pioneering phase of migration, a process of differentiation started in the early 1970s: 
Sikhs called their family earlier; with the arrival of East African Sikhs, they also moved away from industrial, non-qualified employment into self-employment and the professions. This shift explains why they suffered much less than Pakistanis from the acute industrial crisis of the 1970s. This differentiation has resulted in a much better socio-economic profile for Indians as a whole as compared to Pakistanis and Bangladeshis. According to the 2001 census, Sikhs in Britain amount to 450,000 (out of a total of 1 million Indians) and Pakistanis to 750,000.

Among the second and third generation, a South Asian identity has emerged forcefully, that transcends religious, ethnic or national boundaries. As is the case with most minority identity constructions, the South Asian (or Asian) label is in Britain as much an ascribed as an asserted one. Indeed, British Asian 'identity', as experienced especially by the youth, is a product of racism, and of their reactions to it. But besides this reactive aspect, there is a positive identification to this category among the second and third generation, based on the socio-economic commonalities alluded to above, on the rejection of the cleavages of the parent generation, seen as irrelevant in Britain and on the perception of cultural similarities. These cultural similarities (food, dress, social norms...) are given a new transnational dimension by the commoditisation and diffusion of a diasporic culture, through the media of cinema, television and music.

Within this large South Asian category there co-exist several narrower types of identification that nonetheless cut across the national/religious divide. One of the most powerful ones is Panjabyat. This term of recent coinage, roughly translated as Panjabi identity, refers to the cultural heritage, the social practices, the values shared by all Panjabis, Hindus, Muslims and Sikhs, Indians, Pakistanis, and increasingly the diaspora. It is heavily loaded with nostalgia for pre-partition undivided Panjab, idealized as a unique space of communal harmony. Its usage tends to be restricted to intellectual, literary, academic or media circles, and although these valorize popular culture in their definition of Panjabyat, the term is not much used by the people.

It has broadly two acceptations: the loosest one, the most widespread too, especially in the media, refers to its cultural components; the other one has a political content. The issue of language serves as a bridge between cultural and political definitions. In both senses, partition is the critical event, an incomprehensible aberration, a terrible blow to Panjabis and Panjabyat struck variably by the British, the Muslim League or the Congress. Let's examine first the political definition of Panjabyat. For its proponents on both sides of the border, India and Pakistan were created at the cost of a united Panjab, and since then the two nation-states have suppressed Panjabi cultural and political identity, within a centralised political framework. Beyond these common roots and their antagonist relations to the Nation-State, Panjabi nationalist movements have taken very different shapes on each side, reflecting in a way the different position occupied by West Panjab in Pakistan and East Panjab in India. In Pakistan, the overall domination of Panjabis in the army, the bureaucracy and the economy elicits, since the creation of the country, the hostility of the three other Provinces, and their accusation of a 'Panjabisation' of Pakistan. But this domination has been achieved at the cost of Panjabyat, subsumed into Pakistani national identity, through in particular the imposition of Urdu as national language. Hence, (West) Panjabi nationalists' agenda focuses on the issue of language, as their main demand is the use of Panjabi in schools, administration and in the local parliament of West Panjab..$^{13}$ In India, Panjabis are a tiny minority of the overall population (although their share in the economic sector and the army far exceeds their 
demographic weight) and Indian Panjab lies at the periphery of decision making process, both political and economic. Secondly, in India, Panjabyat, in the political and cultural sense, has been the preserve of one religious community, the Sikhs, Panjabi nationalism meaning in fact Sikh nationalism, Panjabyat equating with Sikh identity. And Sikh ethnonationalism has been fashioned since independence by its opposition with the central government, by a sense of alienation, of being discriminated as a minority. Although this confrontation with Delhi has been a long-standing component of Panjabyat (much before independence), it has taken a new form with the rise of Sikh separatism (the demand for Khalistan), and the equation of the central government with the Hindu majority. Besides, in their conflict with the Indian State, it is notorious that Khalistanis have secured some kind of support from Pakistan, thus reconfiguring in a new way the Hindu-Muslim-Sikh triad that we have discussed above.

The most current use of Panjabyat refers to its cultural components. Panjabi language is clearly the most important binding element. Within patterns of code switching, characteristic of most migrants and reinforced by the specific relations of Panjabi to Urdu and Hindi (see below), Panjabi is preferred to convey intimate matters, emotions and jokes. Panjabi is also the medium of a literature, a vernacular corpus of epic poems, folk tales, ballads and songs that has fashioned a common imaginary, spiritual values and social practices and whose most popular figures are Waris Shah and Baba Farid.

51 Promotion of the language and of the literature has been the focus of diasporic Panjabi circles, composed of writers, intellectuals, teachers, some of whom were educated in prepartition Panjab, others, among the youngest partaking of this common British Asian identity that I have mentioned. The World Panjabi Congress, created by Fakhar Zhaman in Lahore, with most of its members in the diaspora, has been the herald of Panjabyat for the past 20 years, and remarkably one where Panjabi Muslims are significantly represented, which is not the case in most organisations. The Association of Panjab Studies, former editor of the International Journal of Punjab Studies, is a rare example in the academic field that provided research on the 'three Panjab', pre-partition, East/West Panjab and the diaspora- although the Sikh / East Panjab component was dominant. The Panjabi Bulletin, edited by a young Sikh from Birmingham, focused on the promotion and preservation of Panjabi folk music, in danger of disappearing both in Panjab and in the diaspora, with the success of commercial music (bhangra).

Let's return to the other cultural components of Panjabyat, to what I have called a Panjabi ethos. To avoid any essentialist slip in my argument, I wish to stress that if there is such a thing as a Panjabi ethos, it is of course not a fixed, objective category, but partly a product of representations and stereotypes fashioned by others. Hence Panjabis' Epicureanism (their unrestricted love for food, drink and festivities), their openmindedness, their sense of hospitality, their romanticism and their anti-intellectualism, as is conspicuous in sardar jokes (jokes about Sikhs) already appear as inscribed, 'inbred' characteristics in colonial literature (see the enduring legacy of the martial races theory). This aspect of Panjabyat has been widely popularised and given an 'hype touch' by commercial music (bhangra, specially) and movie (the archetype being the Bollywood film, Veer Zara, herald of a marketed Panjabyat).

However, major ambiguities weaken also Panjabyat as a potential pan-ethnic type of identification in the diaspora. Firstly, the issue of language is not as consensual as it seems. I have termed it as the strongest bond, it is also a divisive one, through the differentiation between spoken and written language along religious lines. Panjabi has 
three scripts: Persian, Devanagari and Gurmukhi, the sacred language of the Sikhs, the only script specific to Panjabi, whereas the others are used by Urdu for Persian script and Hindi for Devanagari script. Historically the high language, the language of culture and power of North India, including Panjab, was Persian, then Urdu. In the pre-partition period, Urdu and English would be taught at school and Panjabi spoken at home, so that only Sikhs would learn written Panjabi in Gurmukhi script in the gurdwara. These language patterns have consolidated religious boundaries (Rahman 2003). After partition, the cleavage between scripts and oral language along religious affiliation has been reinforced by the national divide, Urdu becoming the national language of Pakistan and Hindi that of India.

These linguistic patterns have been replicated in the diaspora, so that although spoken at home by all Panjabis, Panjabi is written, read and studied only by Sikhs. Hence, they alone demanded in the late 1990s a better share for Panjabi on BBC radio programs on the basis that Panjabi was the mother-tongue of the majority of British South Asians. This situation is reminiscent of the pre-partition period and of the Panjabi Suba campaign in the 1950s, when Panjabi Hindus declared Hindi, instead of Panjabi, as their mother tongue. As a result, Panjabi language and Panjabyat tend to equate in the diaspora as in India with Sikhs, and very little space is left for, or as a matter of fact claimed by Hindus and Muslims.

Another weakness lies in the way the Hindu-Muslim-Sikh triad is been reconfigured within the framework of Panjabyat. Most non-Panjabi Indians resent Panjabyat as antiIndian and anti-Hindu. Indeed they rightly point at the involvement of former Khalistanis, with well established links with the Pakistan government, in Panjabi organisations (such as the World Muslim Sikh Federation, founded in the UK). Beyond these political underpinnings, it seems the triad, as an unstable and unequal set of relations, can only operate at the advantage of a pair and at the cost of a third party. And in the current definition of Panjabyat, Hindus are the third party.

But despite these ambiguities, Panjabyat is been given a new vigour by the improvement of relations between India and Pakistan, of which East and West Panjabi civil societies, through people to people contact, have become major actors. The reopening of borders since 2004 has resulted in a spectacular increase and diversification of exchanges across Wagah border (peace marches, theatre and music tours, cricket tours, and pilgrimages...) to an extent unknown since partition (Blom \& Moliner 2005). It will be interesting to follow their influence on community relations within the diaspora, and in particular in improving relations between Muslims and Sikhs.

\section{Conclusion}

Relationships between minority groups in a migration context are fashioned by a complex combination of variables. In the case of Sikhs and Muslims, representations borrowed from a partly reconstructed past are certainly predominant. The process through which the Muslim came to stand as the dangerous Other for Sikhs started as early as the $18^{\text {th }}$ century, but what weigh the most on relations between the two groups are the events of partition and their crystallisation in each community's memory and narrative. But neither 'hereditary' enmity nor collective memory are immutable. The legacy of partition is being reassessed in South Asia: first by scholars and social activists, now with the relative improvement of Indo-Pakistan relations, by civil society at large, 
even by the film industry (see the recent adaptation of Amrita Pritam's novel Pinjar). In the diaspora, particularly for the youth, the borders and cleavages inherited from partition are increasingly meaningless, and are being superseded by a common South Asian identity, produced by migration, or more regional ones (such as Panjabyat).

But a second variable, the British context and particularly its multicultural framework, tend to rehabilitate these cleavages. While reifying and institutionalizing cultural differences, it encourages minority groups to be internally homogenous (at the expense of plural, overlapping or heterodox definitions of identity) and externally divided by tight boundaries. Besides, Indians as a whole, be they Sikhs or Hindus, have for long been adamant to differentiate themselves from Pakistanis and Bangladeshis: firstly, as part of their process of social mobility, they want to appear as a model minority, with little in common with deprived and marginalized migrant groups; secondly within a context of rising islamophobia in British society, the case of Sikhs in that respect is peculiar as the outward symbols of their faith (their turban and long beard) make the minority of those who wear them in the diaspora ${ }^{14}$ look like radical Muslims.

\section{BIBLIOGRAPHY}

Axel, Brian Keith (2001) The Nation's Tortured Body: Violence, Representation and the Formation of a Sikh 'Diaspora', London \& Durham: Duke University Press.

Banga, Indu (1988) 'Crisis of Sikh Politics', in Joseph O'Connell, Milton Israel \& Willard G. Oxtoby (eds.), Sikh History and Religion in the $20^{\text {th }}$ Century, Delhi: Manohar, pp. 233-55.

Baumann, Gerd (1996) Contesting Culture: Discourses of Identity in Multi-ethnic London, Cambridge: Cambridge University Press.

Blom, Amélie; Moliner, Christine (2005) ‘Le Pakistan: entre guerre et paix avec l'Inde’, Questions Internationales, 15, La Documentation Française, pp. 70-81.

Butalia, Urvashi (1998) The Other Side of Silence, Delhi: Penguin.

Das, Veena (1992) 'Time, Self, and Community: Features of the Sikh Militant Discourse' Contributions to Indian Sociology, 26(2), pp. 245-59.

Fenech, Louis E. (2003) Martyrdom and the Sikh Tradition, Playing the 'Game of Love', Oxford: Oxford University Press.

Grewal, J.S. (1997) Historical Perspectives on Sikh Identity, Patiala: Punjab University.

Jones, Kenneth W. (1973) 'Ham Hindu Nahin: Arya-Sikh Relations, 1877-1905', Journal of Asian Studies, 23(3), pp. 457-75.

Jones, Kenneth W. (1976) Arya Dharm: Hindu Consciousness in $19^{\text {th }}$ century Punjab, Berkeley: University of California Press.

Macauliffe, M.A (1909) The Sikh Religion, Delhi: Low Price Publications.

McLeod, W. Hew (1980) Early Sikh Tradition, Oxford: Oxford University Press. 
McLeod, W. Hew (1987) The Chaupa Singh Rahit-nama, Otago: University Press.

McLeod, W. Hew (1989) Who is a Sikh?, Oxford: Clarendon Press.

McLeod, W. Hew (1990) [1984] Sources for the Study of Sikhism, Chicago: The University of Chicago Press.

McLeod, W. Hew (1999) 'Sikhs and Muslims in the Punjab', South Asia, 22, pp. 155-65.

McLeod, W. Hew (2002) Historical Dictionary of Sikhism, Oxford: Oxford University Press.

Martin, D-C (1995) ‘The Choices of Identity’, Social Identities, 1(1), pp. 5-20.

Pandey, Gyanendra (2001) Remembering Partition, Cambridge: Cambridge University Press.

Rahman, Tariq (2003) [1996] Language and Politics in Pakistan, Karachi: Oxford University Press.

Rushdie, Salman (1995) [1983] Shame, London: Vintage.

Shiromani Gurdwara Parbandhak Committee (1997) Sikh Rahit Maryada, Amritsar.

Sidhu, G.S. (1998) A Challenge to Sikhism, Birmingham: Council of Sikh Gurdwaras in Birmingham.

Sidhu, G.S; Singh, Gurmukh (2001) Sikh Religion and Islam: A Comparative Study, London: Gurdwara Dasmesh Darbar.

Sikh Woman's Awareness Network (1998) Islam and Sikhism: a Comparative View on Women, Akaal Purkh Ki Fauj UK.

Singh, Anita Inder (1987) The Origins of the Partition of India, 1936-1947, Delhi: Oxford University Press.

Singh, Pashaura \& Barrier, N. Gerald (1999) Sikh Identity: Continuity and Change, Delhi: Manohar.

Talbot, Ian; Singh, Gurharpal (eds.) (1999) Region and Partition: Bengal, Punjab and the Partition of the Subcontinent, Oxford: Oxford University Press.

Tan, Tai Yong; Kudaisya, Gyanesh (2000) The Aftermath of Partition in South Asia, London: Routledge.

Tatla, Darshan Singh (1999) The Sikh Diaspora: The Search for Statehood, London: University College Press.

Westwood, Sallie (1995) ‘Gendering Diaspora: Space, Politics and South Asian Masculinities in Britain', in Peter Van der Veer (ed.), Nation and Migration: The Politics of Space in the South Asian Diaspora, Philadelphia: University of Pennsylvania Press, pp. 197-219.

Sikand, Yoginder (2004), 'Re-imagining Sikh-Muslim Relations in the Light of the Life of Baba Nanak', Qalandar.

\section{NOTES}

1. I wish to thank W. Hew McLeod, Denis Matringe, Asif Khan and Aminah Mohammad-Arif for their very helpful comments. The usual disclaimers apply.

2. See among other works: Singh \& Barrier (1999); Tatla (1999); Axel (2001).

3. His favourite target being the Nath Yogis, see McLeod (1980).

4. This subsequent development is borrowed from H. McLeod's unsurpassed study of the JanamSakhi, in Early Sikh Tradition, op.cit. 
5. A religious and militant order created in 1699 by the $10^{\text {th }}$ Guru, whose membership is restricted to those who undergo baptism (armit sanskar) and wear the panj kakkar, the fives Ks, the kirpan, kara, kesh, kanga, khacha.

6. This sanskrit word (literally 'path') 'is used in India to designate groups following particular teachers or doctrines' (McLeod 2002). Written with a capital letter, it refers to the Sikh community alone.

7. Published in Panjabi in 1898, it has since then been augmented, reprinted several times and widely disseminated, but its original title in Hindi has been retained. See a review of this work by Grewal (1997).

8. This analysis draws from Fenech (2003) and Das (1992).

9. See on this period: Banga (1988); Singh (1987); Talbot \& Singh (1999); Tan \& Kudaisya (2000).

10. As recovered by Butalia (1998). See also Pandey (2001).

11. This small town north of Batala is a holy town for the Ahmadiyahs. I thank Prof. McLeod for this information.

12. See on the issue of ethnicity and gender, Westwood (1995).

13. See the most comprehensive study of the Panjabi movement in Rahman (1997).

14. A majority of Sikhs, the mona Sikhs, cut their hair and do not wear a turban though.

\section{ABSTRACTS}

This paper focuses on Sikh representations of the Muslims and the relationships between those two groups sharing a common regional identity, both in the Sub-continent and in the diaspora. It does so diachronically, arguing that historical constructions of the Muslim as the Other (often, but not always, as the enemy) have been instrumental in Sikh identity formation process, since the $18^{\text {th }}$ century onwards. And synchronically, it traces the reshaping of these representations in post-colonial Britain that is home to important Sikh and Muslim populations and the ways they impact on inter-community relationships. 